\title{
Comparative Macroscopic and Microscopic Characterization of Raw Herbal Drugs of Abrus precatorius L. and Glycyrrhiza glabra L.
}

\author{
Pankaj Kumar ${ }^{1,2}$, Javaid Fayaz Lone ${ }^{1,2}$, Sumeet Gairola ${ }^{1,2, *}$
}

\section{Pankaj Kumar ${ }^{1,2}$, Javaid Fayaz Lone ${ }^{1,2}$, Sumeet Gairola ${ }^{1,2, *}$}

'Plant Sciences Division, CSIR-Indian Institute of Integrative Medicine, Canal Road, Jammu, U.T. of J\&K, INDIA. ${ }^{2}$ Academy of Scientific and Innovative Research (AcSIR), Ghaziabad, Uttar Pradesh, INDIA.

Correspondence

Dr. Sumeet Gairola

Scientist, Plant Sciences Division, CSIR-Indian Institute of Integrative Medicine, Canal Road, Jammu-180001, Jammu and Kashmir, INDIA.

Email id: sumeetgairola@iiim.res.in ORCID iD: 0000-0002-2928-1446

\section{History}

- Submission Date: 16-11-2021:

- Review completed: 02-12-2021

- Accepted Date: 23-12-2021

DOI : 10.5530/pres.14.1.14

Article Available online http://www.phcogres.com

Copyright

(c) 2022 Phcog.Net. This is an openaccess article distributed under the terms of the Creative Commons Attribution 4.0 International license.

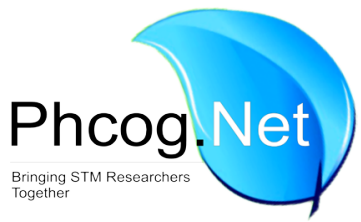

\begin{abstract}
Background: The root of Glycyrrhiza glabra L., also known as 'Licorice,' is used as an expectorant in cough and cold preparations, used to treat hepatitis, and have therapeutic benefit against some other viruses. The roots of Abrus precatorius L. belonging to the family Leguminosae are commonly known as 'Indian wild Licorice.' The roots of both of these plants are used in Indian systems of medicine (I.S.M.) to treat various health ailments. The root of $A$. precatorius is used as a substitute or sometimes as an adulterant of G. glabra. Objectives: The present study aimed to develop comparative standards for easy and fast identification of root drug samples of two selected species. Materials and Methods: The present study involved a comparative macroscopic and microscopic characterization of the root drug samples of G. glabra and A. precatorius using compound and stereo microscopes. Results: Comparative study of qualitative and quantitative characters revealed significant differences in surface and microscopic characters. Anatomical characters such as cortex and phloem zone appearance, the appearance of vascular rays, and some powder characters, i.e., color and taste of powder and shape and size of starch grains, clearly differentiated the genuine 'Liquorice' drug root samples from other drug species. Conclusion: Botanical characters compiled in the present study can be used as a reference standard for future identification of individual raw root drug samples and the comparative distinction of both species' root samples.
\end{abstract}

Key words: Raw root herbs, Licorice, Macroscopic and microscopic studies, Identification characters, Reference standards.

\section{INTRODUCTION}

The Leguminosae family is the most prominent angiosperm family, with around 730 genera and more than 19,400 species. $^{[1]}$ Several species of this family are used by various indigenous communities in India's different regions. ${ }^{[2-6]}$ Glycyrrhiza glabra L. and Abrus precatorius L. belonging to the family Leguminosae are commonly known as 'Licorice' and 'Indian wild Licorice,' respectively (Table 1). The roots of $A$. precatorius are used as an adulterant of genuine 'Liquorice' or G. glabra. ${ }^{[7-9]}$ Roots of A. precatorius are considered as an emetic, diuretic, and alexiteric, used to treat sore throat, rheumatism, bronchitis, cold, cough, diarrhea, abdominal pain, gastritis, insomnia, gonorrhea, tumors, cancer, snake bite, heart diseases, kidney diseases, jaundice, hepatitis, and other viral infections. ${ }^{[10-12]}$ Root and rhizome of G. glabra affect memory, spatial learning, passive avoidance [13,14] and minimize serum testosterone levels in men. ${ }^{[15,16]}$ G. glabra roots contain several significant bioactive chemicals, known with important pharmacological properties such as antimicrobial, antioxidant, anxiolytic, anti-carcinogenesis, and antidiabetic properties. ${ }^{[17-19]}$ Licorice is used as an expectorant in cough, cold preparations, and treating hepatitis, and have therapeutic benefits against other viruses, including cytomegalovirus (CMV) and human immunodeficiency virus herpes simplex, etc. ${ }^{[20]}$ Roots of $A$. precatorius are reported to have abrol, abrasine, abraline, abricin, abrusogenic acid, abrussic acid, abruslactone A, methyl abrusgenate, precol, precasine, and glycyrrhizin. ${ }^{[21,22]}$ Roots of Glycyrrhiza glabra are reported to have triterpenoid compounds (Glycyrrhizin, Glycyrrhetinic acid, and liquirtic acid), flavonoids, isoflavonoids (liquiritin, isoliquiritin, formononetin), and other chemical constituents. ${ }^{[23-25]}$

The estimated annual trade of $A$. precatorius and G. glabra in the Indian herbal market is $200-500$ MT and 2000-5000 MT, respectively. ${ }^{[26]}$ The root of G. glabra is considered as genuine source of 'Licorice,' which is often reported to be interchangeably used with the root of $A$. precatorius. Herbal samples of some other species are also reported to be used in place of both A. precatorius and G. glabra (Table 1). Herbal drug samples are generally procured in dried, fragmented, broken, or powdered form in the herbal industry. The raw material of dry root samples generally lacks specific vegetative

Cite this article: Kumar P, Lone JF, Gairola S. Comparative Macroscopic and Microscopic Characterization of Raw Herbal Drugs of Abrus precatorius L. and Glycyrrhiza glabra L.. Pharmacog Res. 2022;14(1):100-6. 
Table 1: Details of the studied raw root drug samples (R.D.S.) of A. precatorius and G. glabra.

\begin{tabular}{|c|c|c|c|}
\hline S.No. & Character & \multicolumn{2}{|c|}{ Plant species } \\
\hline 1 & Botanical name $e^{[30]}$ & Abrus precatorius $\mathrm{L}$. & Glycyrrhiza glabra L. \\
\hline 2 & Synonyms & $\begin{array}{l}\text { Abrus abrus (L.) Wright, Abrus minor Desv., Glycine } \\
\text { abrus L. }\end{array}$ & $\begin{array}{l}\text { Glycyrrhiza brachycarpa Boiss., Glycyrrhiza hirsuta } \\
\text { Pall., Glycyrrhiza violacea Boiss. and Noe }\end{array}$ \\
\hline 3 & Distribution & $\begin{array}{l}\text { Throughout the plains up to an altitude of } 1200 \mathrm{~m} \text { asl; } \\
\text { ranging from Himalaya to Southern parts }{ }^{[31]}\end{array}$ & $\begin{array}{l}\text { Sub-tropical and warm temperate regions, cultivated } \\
\text { in many parts of India }{ }^{[7]}\end{array}$ \\
\hline 4 & Collection place (asl) & Dadwara, Billawar, UT of J\&K (wild) & IIIM campus, Jammu, UT of J\&K (cultivated) \\
\hline 5 & G.P.S. location & N $32^{\circ} 33.917^{\prime}$ E $075^{\circ} 32.064^{\prime}$ & $\mathrm{N} 32^{\circ} 43.855^{\prime}$ E $074^{\circ} 51.059^{\prime}$ \\
\hline 6 & Altitude & $621 \mathrm{~m}$ asl & $304 \mathrm{~m}$ asl \\
\hline 7 & Herbarium No. & RRLH-23814 & RRLH-24233 \\
\hline 8 & Raw drug accession No. & CDR-4136 & CDR-4157 \\
\hline 9 & Ayurvedic name ${ }^{[7,32]}$ & $\begin{array}{l}\text { Gunjaa, Gunjaka, Chirihintikaa, Raktikaa, Chirmiti, } \\
\text { Kakanti, Kabjaka, Tiktikaa, Kaakananti, Kaakchinchi }\end{array}$ & $\begin{array}{c}\text { Yashtimadhu, Madhuyashtyaahvaa, Madhuli, } \\
\text { Madhuyashtikaa, Atirasaa, Madhurasaa, Madhuka, } \\
\text { Yastikaahva, Yashtyaahva, Yashti, Yashtika, } \\
\text { Yashtimadhuka }\end{array}$ \\
\hline 10 & Local/Trade name & $\begin{array}{l}\text { Jequirity, Indian wild Liquorice, Crab’s Eye, Rosary } \\
\text { pea, Ratti, Precatory Bean, Gundumani, Gunja, } \\
\text { Gaunchi, Chirmati, Chinnoti, Mulati, Kakananti, } \\
\text { Shangir }{ }^{[10,31]}\end{array}$ & $\begin{array}{l}\text { Licorice, Liquorice root, Mulathi, Jeshtimadhu, } \\
\text { Jethimadhu, Gulegafis, Yasti } 7,26\end{array}$ \\
\hline 11 & Estimated annual trade $\mathrm{e}^{[26]}$ & 200-500 MT & 2000-5000 MT \\
\hline 12 & Habit and habitat & $\begin{array}{l}\text { Much-branched, perennial, deciduous, woody twining } \\
\text { herb, mature stem woody }\end{array}$ & $\begin{array}{c}\text { A small perennial herb or undershrub, up to } 2 \mathrm{~m} \text { high, } \\
\text { grows in sub-tropical and warm temperate regions. It } \\
\text { can be seen growing in fertile, sandy, or clay soil near } \\
\text { a river or stream }\end{array}$ \\
\hline 13 & Distribution in India & $\begin{array}{l}\text { It is distributed from the Himalayas to Southern parts } \\
\text { throughout the plains, up to } 1200 \mathrm{~m} \cdot{ }^{[31]}\end{array}$ & $\begin{array}{c}\text { Cultivated in Punjab, Jammu and Kashmir, and South } \\
\text { India. }\end{array}$ \\
\hline 14 & Ayurvedic uses & Indralupta, Mukhasosa, Sula ${ }^{[32]}$ & Kasa, Ksaya, Svarabheda, Vatarakta, Vrana ${ }^{[32]}$ \\
\hline 15 & Ayurvedic formulations & Nili Bhrngadi Taila ${ }^{[32]}$ & $\begin{array}{c}\text { Eladi Guika, Yastimadhuka Taila, Madhuyastyadi } \\
\qquad \text { Taila }^{[32]}\end{array}$ \\
\hline 16 & Major chemical compounds & $\begin{array}{l}\text { Abrasine, abrol, abrine, abruquinones, abrusgenic } \\
\text { acid, choline, precatorine. }{ }^{[33]}\end{array}$ & $\begin{array}{c}\text { Glycyrrhizin, glycyrrhizic acid, glabranins, Liquorice, } \\
\text { liquiritic, glyzarin. } .^{(9]}\end{array}$ \\
\hline 17 & $\begin{array}{c}\text { Adulterants/ Potential confounding } \\
\text { material }\end{array}$ & $\begin{array}{c}\text { Abrus fruticulosus Wight and Arn., Abrus laevigatus E. } \\
\text { May. (Shveta Gunjaa). }{ }^{[7,33]}\end{array}$ & $\begin{array}{l}\text { Some other species of Glycyrrhiza and root of Abrus } \\
\text { precatorius Linn. }{ }^{[8]} \text { Indigofera tinctoria. }{ }^{[7,33]}\end{array}$ \\
\hline
\end{tabular}

taxonomic features, and it is comparatively challenging to identify than aerial herbal samples. Correct identification and authentication of raw herbal drugs are essential to ensure herbal medicines' correct identity, quality, and efficacy. ${ }^{[27]}$ Because of the above consideration, the present study aimed to develop botanical identification standards to distinguish both species' raw root drug samples. Detailed macroscopic and microscopic characterization (transverse sections and powder samples) were done on root drug samples of the selected two species using a stereo-microscope and light microscope. Comparative studies of crude drug samples revealed some characteristic features that can help identify and differentiate root drug samples of two species.

\section{MATERIALS AND METHODS}

\section{Plant collection and identification}

The authentic plant material (for herbarium sheets, crude raw specimens, and botanical studies) was collected from the two different locations of U.T. of Jammu and Kashmir (Table 1). For anatomical studies, samples were collected in Formalin-Acetic acid-Alcohol fixative (F.A.A.): Formalin $(5 \mathrm{ml})+$ Acetic acid $(5 \mathrm{ml})+70 \%$ Ethyl alcohol $(90 \mathrm{ml})$; (stored for $24 \mathrm{hr}$ then transferred to $70 \%$ alcohol). Herbarium sheets were prepared following standard herbarium procedures. ${ }^{[28]}$ Duly identified herbarium specimens were submitted to the internationally recognized
Janaki Ammal Herbarium (RRLH) at the Indian Institute of Integrative Medicine (CSIR-IIIM), Jammu. Oven-dried raw herb samples were submitted to the Crude Drug Repository at CSIR-IIIM Jammu.

\section{Botanical studies \\ Macroscopic studies}

The macroscopic study involved color, texture, the root surface's appearance, and organoleptic characters of root powder samples were done using a stereo-microscope (LEICA S9i).

\section{Anatomical studies}

Fine transverse sections (T.S.) were obtained for the anatomical study by freehand sectioning using a razor blade. Fine sections were stained as per Kumar et al. ${ }^{[29]}$ with minor modifications. The T.S. was dehydrated in a series of alcohol gradients (50\% and 70\% alcohol, each for 10-15 $\mathrm{min}$ ), stained in safranin stain (5-10 min), and then was decolorized in $70 \%$ alcohol (5-10 $\mathrm{min})$. The sections were again stained in fast green (3-5 $\mathrm{min}$ ), decolorized in 70\% alcohol (3-5 $\mathrm{min}$ ), followed by dehydration in $90 \%$ alcohol and by absolute alcohol (5-7 min each). The sections were cleared in xylene and finally mounted in Canada balsam. The final sections were examined under a compound microscope (LEICA DM 750) and photographed with an attached camera (LEICA ICC50E). 


\section{Powder studies}

The root powder samples were crushed into powdery mass, passed through a sieve to obtain a fine powder, and used for organoleptic and microscopic studies. The water-mounted slides were examined under a compound microscope to study the various cell types and cell contents.

\section{Micrometric measurements}

For micrometric measurements of transverse sections, 3-5 sections of nearly $2-5 \mathrm{~mm}$ diameter were selected. For each section, the size of various tissue zones was measured to the transverse section's radius. Besides, the dimensions of different cells, lumen diameter of xylem vessels, size of starch grains, etc., were also measured.

\section{RESULTS}

\section{Taxonomical study}

The taxonomic details and comparative macroscopic and microscopic observations have been given in Tables 1, 2, and Figure 1. Abrus precatorius is a perennial, much-branched climber with pinnately compound leaves having 10-15 pairs of oblong-shaped, compound paripinnate leaflets resembling tamarind leaves (Figure A1). Glycyrrhiza glabra is a small perennial herb or undershrub ( $2 \mathrm{~m}$ high) with 4-7 pairs of oblong, elliptical or lanceolate, compound imparipinnate leaflets (Figure B1).

\section{Macroscopic characters of root}

Abrus precatorius: Root is woody, cylindrical, or irregularly curved to tortuous, $0.2-1.5 \mathrm{~cm}$ thick, with few branches (Figure A2). Surface light brown to buff-colored, rough, warty, corky, and flaky with transverse cracks (Figure A3). Cut root circular in outline, with thick, brown bark, internally lined with a thin silver-colored ring. The central zone comprised a light brown woody part with numerous randomly distributed pores of varying size, traversed by several creamish rays emerging in the form of spokes of a wheel from the central region (Figure A4). The thickness of rays appeared nearly uniform from the center to the outer region.

Glycyrrhiza glabra: Root is cylindrical, straight, or with bends, elongated, $0.2-1.0 \mathrm{~cm}$ thick, and with few secondary branches (Figure B2). Root yellowish brown, surface smooth with longitudinal cracks in young roots. Mature root surface rough and corky (Figure B3). Cut root circular in outline with light brown colored, thin, corky, bark region. Internal to the cork zone, cut root appeared of three main zones. The outermost zone formed of creamish white zone having alternating reddish-brown rays, followed by inner creamish white porous region alternated with light brown spoke like rays and central circular reddish-brown pith region (Figure B4).

\section{Microscopic characters of root}

A detailed comparative microscopic study of root sections of both species (A. precatorius and G. glabra) showed similar anatomical arrangements of some tissues (Figure A5, B5). Both species were observed with a circular outline of T.S. having outer irregular, broken, thin cork zone; inner cortex and phloem zone (comparatively broader in G. glabra), a thin cambium zone separating phloem and xylem tissue. Phloem and xylem tissue zones were present in a ray-like pattern, with each ray being separated from others by the parenchymatous medullary ray. Xylem vessels of variable lumen diameter were present in a spoke-like pattern in both species. A nearly circular to slightly angular pith was present in the center of the T.S. of the root of G. glabra. Root and stolon of G. glabra are reported similar in anatomical tissue arrangement, except for the absence of pith in T.S. of the root. ${ }^{[9]}$ Quantitative characters of transverse sections to the studied radius of the studied section are given in Table 2. Abrus precatorius: The T.S. of the root was circular in outline (Figure A5) with the outermost irregular, broken, thin cork zone $(62.25 \pm 8.57 \mu \mathrm{m})$ having compact lignified, rectangular-shaped cells. Cork was followed by the parenchymatous cortex zone with compactly packed cells, interspersed with a continuous ring of the stone layer in the cortex zone.

Table 2: Quantitative microscopic characters of the T.S. of the root of A. precatorius and G. glabra.

\begin{tabular}{|c|c|c|c|c|c|c|}
\hline \multirow[b]{2}{*}{ Character } & \multicolumn{3}{|c|}{ A. precatorius ( $\mu \mathrm{m})$} & \multicolumn{3}{|c|}{ G. glabra $(\mu \mathrm{m})$} \\
\hline & Min & Max & Mean ( \pm S.E.) & Min & Max & Mean ( \pm S.E.) \\
\hline The radius of studied root T.S. & 953.63 & 1144.42 & $1073.35 \pm 23.93$ & 1725.51 & 2758.99 & $1944.76 \pm 104.76$ \\
\hline Cork zone & 32.35 & 114.64 & $62.25 \pm 8.57$ & 51.99 & 97.61 & $76.28 \pm 4.64$ \\
\hline Cortex + Phloem zone & 209.05 & 353.89 & $268.78 \pm 16.45$ & 340.43 & 761.47 & $556.79 \pm 37.02$ \\
\hline Xylem zone & 642.23 & 845.59 & $747.13 \pm 17.33$ & 477.46 & 1145.4 & $725.16 \pm 59.82$ \\
\hline Vessel lumen diameter & 16.4 & 92.26 & $52.32 \pm 8.19$ & 34.50 & 74.6 & $54.48 \pm 4.79$ \\
\hline Pith zone & - & - & - & 501.00 & 802.14 & $588.11 \pm 28.23$ \\
\hline \multicolumn{7}{|c|}{ Cork cell size } \\
\hline Length & 15.74 & 34.26 & $24.09 \pm 1.62$ & - & - & - \\
\hline Breadth & 11.95 & 17.31 & $13.91 \pm 0.56$ & - & - & - \\
\hline \multicolumn{7}{|c|}{ Cortex cell size } \\
\hline Length & 18.44 & 38.40 & $25.78 \pm 2.30$ & 51.71 & 78.00 & $61.47 \pm 2.75$ \\
\hline Breadth & 8.40 & 15.20 & $11.24 \pm 0.66$ & 30.19 & 52.24 & $38.21 \pm 2.69$ \\
\hline \multicolumn{7}{|c|}{ Pith cell size } \\
\hline Length & - & - & - & 31.70 & 121.30 & $79.69 \pm 8.49$ \\
\hline Breadth & - & - & - & 41.30 & 98.20 & $66.70 \pm 5.63$ \\
\hline \multicolumn{7}{|c|}{ Starch grains size } \\
\hline Length & 4.50 & 12.70 & $7.65 \pm 0.79$ & 8.70 & 15.50 & $10.88 \pm 0.70$ \\
\hline Breadth & 3.90 & 10.30 & $6.18 \pm 0.66$ & 6.50 & 12.90 & $8.09 \pm 0.67$ \\
\hline
\end{tabular}



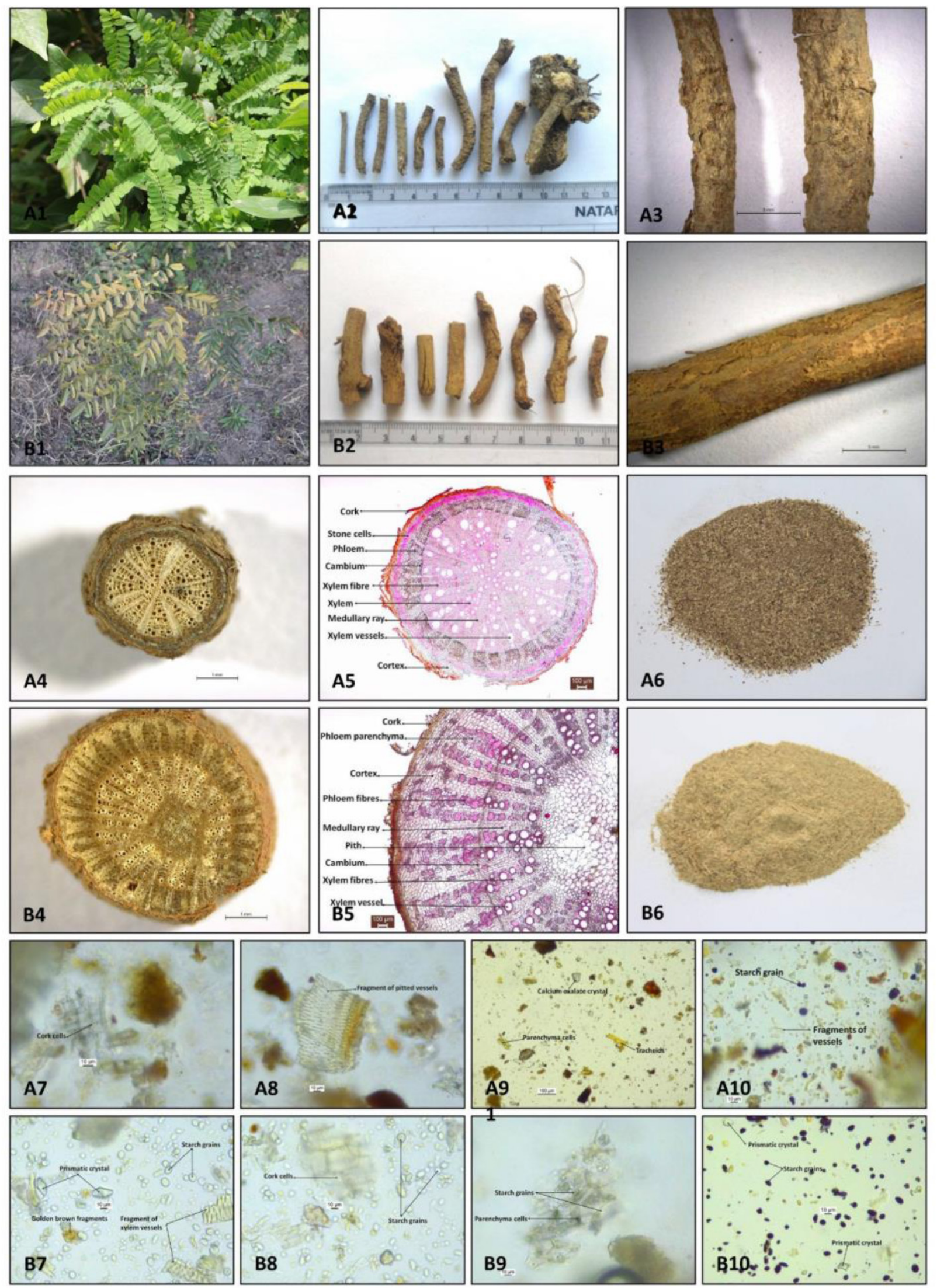

Figure 1: A- series). A. precatorius, B- series). G. glabra; A1 and B1). Plant habit, A2 and B2). Dry root drug sample, A3 and B3). Root surface appearance, A4 and B4). Cut root surface, A5 and B5). Transverse section of root, A6 and B6). Root powder sample, A7-A10 and B7-B10). Powder microscopic characteristics. 
Cortex was followed by a distinct dark-colored phloem zone separated by thin parenchymatous ray-like structures. Cortex and phloem formed a thickness of $268.78 \pm 16.45 \mu \mathrm{m}$. Xylem tissue present in the form of rays and formed a major part $(747.13 \pm 17.33 \mu \mathrm{m})$ in the total radius of T.S. of the studied root (mean radius of $1073.35 \pm 23.93 \mu \mathrm{m}$ ). Xylem consisted of distinct fibers, parenchyma cells, and xylem vessels. Xylem vessels observed of variable lumen diameter $(16.40 \mu \mathrm{m}$ to $92.26 \mu \mathrm{m})$ with a mean lumen diameter of $52.32 \pm 8.19 \mu \mathrm{m}$, were observed present in a spoke-like pattern with uneven distribution. Each xylem ray was separated by thick medullary rays (2-8 cells wide). Pith absent.

Glycyrrhiza glabra: The T.S. of the root was circular in outline (Figure B5) with outermost nearly circular, thin $(76.28 \pm 4.64 \mu \mathrm{m})$, lignified cork zone formed of compactly packed cells. Cork was followed by a narrow cortex zone (3-5 cells wide) with parenchymatous, oval-shaped, compactly packed cells and inner radially elongated wide phloem zone. Phloem was present in a ray-like pattern and appeared patchy due to the presence of phloem parenchyma interspersed by phloem fibers. Each phloem's rays were separated from the other by parenchymatous cortical cells. Cortex and phloem formed a thickness of $556.79 \pm 37.02 \mu \mathrm{m}$ in the total radius of the studied root (mean radius $1944.76 \pm 104.76 \mu \mathrm{m}$ ). Next to the phloem, a thin cambium layer was present, which separated phloem and xylem tissue. Xylem present in ray-like structure, formed a thickness of $725.16 \pm 59.82 \mu \mathrm{m}$ and consisted of distinct fibers, xylem parenchyma, and xylem vessels. Xylem vessels were present in spoke or ray-like pattern with variable lumen diameter $(34.50 \mu \mathrm{m}$ to $74.60 \mu \mathrm{m}$ with a mean lumen diameter of $54.48 \pm 4.79 \mu \mathrm{m})$. Each xylem ray was separated by $4-7$ cell thick medullary rays. A broad pith $(588.11 \pm 28.23 \mu \mathrm{m})$ was present in the center of section.

\section{Powder characteristics}

Abrus precatorius: Root powder was greyish brown with some creamish white fragments (Figure A6), odor was characteristic slightly pleasant, texture gritty to sandy, and no characteristic taste. The microscopic study revealed the presence of few fragments of cork cells (Figure A7), parenchyma cells, numerous vessels with pitted walls and reticulate thickening (Figure A8), few tracheids fragments, prismatic calcium oxalate crystals, and few parenchyma cells (Figure A9), round to ovalshaped starch grains (Figure A10), and several reddish-orange or varied colored fragments (Figures A7-A10).

Glycyrrhiza glabra: Root powder was creamish yellow-colored (Figure B6) with a characteristic pleasant odor, flaky texture, and sweet taste. Microscopic examination of powder was observed with the presence of few prismatic crystals, few golden brown fragments, fragments of pitted xylem vessels with reticulate thickenings (Figure B7), cork cells (Figure B8), parenchyma cells with starch grains (Figure B9), prismatic crystals, and abundant spheroidal to elongated starch grains (Figures B7-B10).

\section{DISCUSSION}

Herbal drug samples in the crude form are difficult to identify and are often adulterated with other herbs. Plant samples with similar common names or samples belonging to the same family may show superficial resemblance, making identification of genuine herbal samples difficult. ${ }^{[34,35]}$ Root drugs of both species (A. precatorius and G. glabra) have different phytochemicals and pharmacological activities (Table 1). Botanical keys often lack taxonomic identification information on dry bark and underground drug samples making herbal drug identification difficult. $^{[36]}$ In various modern pharmacopeia monographs, macromorphological description (describing size, shape, relative form, and physical appearance of crude herbal drugs) and organoleptic description of plant drugs (flavor and nature of drugs) are helpful in the identification of medicinal plants. ${ }^{[36]}$ Among several identifications and quality assurance methods, botanical identification of raw herbal drugs is considered simple, easy, reliable, time, and cost-effective. ${ }^{[37,38]}$ Detailed comparative botanical (macroscopic and microscopic) studies, including qualitative and quantitative features, can help identify herbal drugs. ${ }^{[38,39]}$

The present study involved a detailed comparative macroscopic and microscopic characterization of root drug samples of A. precatorius and G. glabra, which revealed the significant characters of taxonomic value in distinguishing root drug samples of both species. A comparative study showed similarity in only a few characters in both species. The study of plant habit revealed compound pinnate leaves in both species; however, with a variable number of leaflets (Figure A1, B1). Similarly, root drug samples of both species were observed with nearly similar physical appearance of, nearly circular-cut root surface (with variation in internal appearance), spoke like appearance of vascular rays in both the species. Some qualitative and quantitative anatomical characters such as the width of medullary rays, the thickness of cork and xylem zone, lumen diameter of xylem vessels, etc. were slightly variable. However, both species significantly differed in some characters including surface features (color and texture of root surface), the appearance of cortex and phloem tissues (phloem being small patchy zone over xylem rays in A. precatorius while radially elongated and interspersed with parenchyma and phloem fiber in G. glabra), the arrangement of xylem vessels, dilation of medullary rays (more dilation in G. glabra), cortex cell size (larger in G. glabra, Table 2), presence of stone layer in the cortex (A. precatorius) (Figure A5), presence of pith (in G. glabra) (Figure B5). Powder study revealed nearly similar microscopic cell types and ergastic contents, but variation was observed in organoleptic and some selected microscopic features. Variation was observed in color of the powder sample (greyish brown in A. precatorius while creamish yellow in G. glabra) (Figure A6, B6), taste (sweet in G. glabra), and texture (gritty and sandy in A. precatorius, flaky in G. glabra); and in starch grains characters (abundant starch grains with spheroidal to elongated shape in G. glabra while few oval to rounded starch grains in A. precatorius) (Figure A10, B10).

Macroscopic and microscopic studies available on leaf, stem, and fruit of Abrus precatorius. ${ }^{[40,41]}$ Sawant et al..$^{[8]}$ studied qualitative macroscopic and microscopic characters of the root of G. glabra and observed broad elongated phloem (with a group of fibers) and xylem rays (with xylem vessels, fibers), each ray separated by medullary rays, without pith in T.S. of the root. In several botanical studies, different microscopic characters were reported of taxonomic value in species characterization. Ozoemenam et al..$^{[2]}$ observed variations in the comparative anatomical characters of herbal samples of various species of Abrus. Zhang et al. ${ }^{[43]}$ studied comparative microscopic studies on two Abrus species and observed xylem vessel arrangement, the number of xylem rays, and medullary ray thickness as characteristic features in the authentication of root samples of A. cantoniensis and A. mollis. Balazs et al. ${ }^{[44]}$ reported variations in stele structure and the thickness of various tissue types in the root cross-section of three species of Helleborus spp. Li et al. ${ }^{[45]}$ observed the presence of stone cells in the cortex and phloem of roots as helpful in species authentication. Various ergastic cell contents such as starch grains and prismatic crystals are also considered helpful in identifying and characterizing herbal drug material. ${ }^{[46,47]}$ Several quantitative anatomical characters such as the thickness of various tissue zones to studied transverse section, ${ }^{[39]}$ size of epidermal, hypodermal, cortical cells, the appearance of various tissues in cross-section, size of starch grains, ${ }^{[48]}$ are considered as characteristic features and helpful in the identification of raw herbal drugs of different species.

In the present study, various macroscopic and microscopic (anatomical and powder) features of root drug samples described for each species can be used as a reference standard for future identification of two species, in the authentication and distinction of raw root drug samples of genuine 
'Liquorice' drug. A comparative study also revealed the significant botanical characters that can be used to distinguish raw root herbal samples of both species.

\section{CONCLUSION}

From botanical characters summarised in the present study, genuine 'Liquorice' (G. glabra) was distinguished from the adulterant drug (A. precatorius). Root drug samples of both species can be distinguished from botanical characters, including surface appearance, presence of stone layer in the cortex (in A. precatorius), the appearance of cortex and phloem tissue, cortex cell size, vascular rays, presence of pith, organoleptic characters of powder (color and taste), and shape and size of starch grains. Characters identified in the present study can be used as botanical reference standards in the future identification of raw root herbal samples of both species.

\section{ACKNOWLEDGEMENT}

The authors thank Director IIIM Jammu for providing the necessary facilities to carry out the work. The authors are thankful to the Council of Scientific and Industrial Research (CSIR), Government of India, for financial assistance under the Major Lab Project (MLP-1007). P.K. acknowledges the financial support provided by CSIR in the form of JRF/ SRF fellowships.

\section{CONFLICT OF INTEREST}

The authors declare no conflict of interest.

\section{ABBREVIATIONS}

CMV: Cytomegalovirus; FAA: Formalin + Acetic acid + Alcohol (ethyl alcohol); ISM: Indian systems of medicine; MT: Metric Tonnes; RDS: Raw Drug Sample; RRLH: Regional Research Laboratory Herbarium; TS: Transverse Sections.

\section{REFERENCES}

1. Rahman AHMM, Parvin MIA. Study of medicinal uses on Fabaceae family at Rajshahi, Bangladesh. Res Plant Sci. 2014;2:6-8.

2. Sharma J, Gairola S, Gaur RD, Painuli RM. The treatment of jaundice with medicinal plants in indigenous communities of the Sub-Himalayan region of Uttarakhand, India. J Ethnopharmacol. 2012;143(1):262-91. doi: 10.1016/j. jep.2012.06.034, PMID 22759701.

3. Sharma J, Gairola S, Gaur RD, Painuli RM, Siddiqi TO. Ethnomedicinal plants used for treating epilepsy by indigenous communities of sub-Himalayan region of Uttarakhand, India. J Ethnopharmacol. 2013;150(1):353-70. doi: 10.1016/j. jep.2013.08.052, PMID 24029249.

4. Sharma J, Gaur RD, Gairola S, Painuli RM, Siddiqui TO. Traditional herbal medicines used for the treatment of skin disorders by the Gujjar tribe of SubHimalayan tract, Uttarakhand. Ind J Tradit Knowl. 2013;12:736-46.

5. Sharma J, Gairola S, Sharma YP, Gaur RD. Ethnomedicinal plants used to treat skin diseases by Tharu community of district Udham Singh Nagar, Uttarakhand, India. J Ethnopharmacol. 2014;158(A):140-206. doi: 10.1016/j.jep.2014.10.004, PMID 25448505.

6. Gairola S, Sharma J, Bedi YS. A cross-cultural analysis of Jammu, Kashmir and Ladakh (India) medicinal plant use. J Ethnopharmacol. 2014;155(2):925-86. doi: 10.1016/j.jep.2014.06.029, PMID 24952280.

7. Khare CP. Indian medicinal plants: An illustrated dictionary. Springer; 2007.

8. Sawant BS, Alawe JR, Rasal KV. Pharmacognostic study of Glycyrrhiza glabra Linn- A review. Int Ayur J. 2016;4:3188-93

9. ICMR. Quality standards of Indian medicinal plants. Medicinal plants unit. Vol. 9. New Delhi: Indian Council of Medical Research; 2011. p. 175-86.

10. Kirtikar KR, Basu BD. Indian Medicinal plants. $2^{\text {nd }}$ ed, vol-I, International book distributors. Dehradun; 2005. p. 763-7.

11. Daniel M. Medicinal Plants: Chemistry and properties. 1st ed, Oxford and I.B.H. Publishing House Co. Pvt. Ltd, New Delhi. 2006;118-119.

12. Attal AR, Otari KV, Shete RV, Upasani CD, Nandgude TD. Abrus precatorius Linnaeus: A phytopharmacological review. J Pharm Res. 2010;3:2585-7.

13. Ravichandra V, Ahalyadevi AS. Evaluation of the effect of Glycyrrhiza glabra Linn root extract on spatial learning and passive avoidance response in rats. Indian
Drugs. 2007;44:214-19.

14. Chakravarthi KK, Avadhani R. Effect of Glycyrrhiza glabra root extract on learning and memory in Wistar albino rats. Drug Inv Today. 2012;4:387-90.

15. Armanini D, Bonanni G, Palermo M. Reduction of serum testosterone in men by licorice. N Engl J Med. 1999;341(15):1158. doi: 10.1056/NEJM199910073411515 PMID 10515764.

16. Armanini D, Fiore C, Mattarello MJ, Bielenberg J, Palermo M. History of the endocrine effects of licorice. Exp Clin Endocrinol Diabetes. 2002;110(6):257-61. doi: 10.1055/s-2002-34587, PMID 12373628

17. Roshan A, Verma NK, Kumar CS, ChandraV, Singh DP, Pandey MK. Phytochemical constituent, pharmacological activities and medicinal uses through the millennia of Glycyrrhiza glabraLinn: a review. Int Res J Pharm. 2012;3:45-55.

18. Damle M. Glycyrrhiza glabra (Liquorice) - a potent medicinal herb. Int J Herb Med. 2014;2:132-6.

19. Pastorino G, Cornara L, Soares S, Rodrigues F, Oliveira MBPP. Liquorice (Glycyrrhiza glabra): A phytochemical and pharmacological review. Phytothe Res. 2018;32(12):2323-39. doi: 10.1002/ptr.6178, PMID 30117204.

20. Zadeh JB, Kor ZM, Goftar MK. Licorice (Glycyrrhiza glabra Linn) as a valuable medicinal plant. Int J Adv Biol Biomed Res. 2013;1:1281-8.

21. Choi YH, Hussain RA, Pezzuto JM, Kinghorn AD, Morton JF. Abrusosides A-D, Four novel sweet-tasting triterpene glycosides from the leaves of Abrus precatorius. J Nat Prod. 1989:52(5):1118-27. doi: 10.1021/np50065a032, PMID 2691636.

22. Saxena VK, Sharma DN. A new isoflavone from the roots of Abrus precatorius Fitoterapia. 1999;70(3):328-9. doi: 10.1016/S0367-326X(99)00036-2.

23. Bradley PR. British herbal compendium. Vol. 1. Bournemouth: BHMA; 1992.

24. Fukai T, Cai B, Maruno K, Miyakawa Y, Konishi M, Nomura T. An isoprenylated flavanone from Glycyrrhiza glabra and rec-assay of licorice phenols1Part 22 in the series "phenolic constituents of Glycyrrhiza species". For part 21, see the article by Fukai et al. [Fukai, T., Cai, B.-S., Horikosi, T. and Nomura, T., Phytochemistry, 1996, 43, 1119.]. Phytochemistry. 1998;49(7):2005-13. doi: 10.1016/S0031-9422(98)00389-6.

25. Arystanova TP, Irismetov MP, Sopbekova AO. Chromatographic determination of glycyrrhizinic acid in Glycyrrhiza glabra preparation. Chem. Chem Nat Compd. 2001;37(1):89-90. doi: 10.1023/A:1017675115337.

26. NMPB. Traded medicinal plant [Database:2020].

27. Sahoo N, Manchikanti P, Dey S. Herbal drugs: Standards and regulation. Fitoterapia. 2010;81(6):462-71. doi: 10.1016/j.fitote.2010.02.001, PMID 20156530.

28. Rao RR, Sharma BD. A manual for herbarium collections. Botanical Survey of India. 1990.

29. Kumar P, Singh K, Gairola S. Botanical standardization of raw herbal drug Pashanabheda [Bergenia ciliata (Haw.) Sternb.] used in Indian Systems of Medicine. Plant Arch. 2020;20:8645-52.

30. T.P.L.; 2013 [cited Sep 17 2020]. Available from: http://www.theplantlist.org

31. Nadkarni KM. Indian materia medica. $5^{\text {th }}$ ed, Vol-I, Popular Prakashan. Mumbai; 1999. p. 4-7.

32. API. The ayurvedic pharmacopoeia of India. Part-I, vols. Department of AYUSH India: Government of India, Ministry of Health and Family Welfare; 2001. p. I-V.

33. ICMR. Quality standards of Indian medicinal plants. Medicinal plants unit. Vol. 8. New Delhi: Indian Council of Medical Research; 2010. p. 9-17.

34. Khan MAMS, Qureshi RA, Soomro R. Matricaria chamomella (Chamonile, Babuna) Problems of its identification and Medicinal uses. Pro First Train Workshop Ethnob Appl. Conserv. National Herbarium PASA/(NARC, Islamabad, Pakistan). Vol. 16(September); 1996. p. 104-12

35. Joharchi MR, Amiri MS. Taxonomic evaluation of misidentification of crude herbal drugs marketed in Iran. Avicenna J Phytomed. 2012:2(2):105-12. PMID 25050238.

36. Upton R, David B, Gafner S, Glasl S. Botanical ingredient identification and quality assessment: strengths and limitations of analytical techniques. Phytochem Rev. 2020;19(5):1157-77. doi: 10.1007/s11101-019-09625-z.

37. Li J, Yi T, Lai HS, Xue D, Jiang H, Peng HC, et al. Application of microscopy in authentication of traditional Tibetan medicinal plant Halenia elliptica. Microsc Res Tech. 2008;71(1):11-9. doi: 10.1002/jemt.20518, PMID 17902179.

38. Akbar S, Hanif U, Ali J, Ishtiaq S. Pharmacognostic studies of stem, roots and leaves of Malva parviflora L. Asian Pac J Trop Biomed. 2014;4(5):410-5. doi: 10.12980/APJTB.4.2014C1107, PMID 25182728.

39. Hassan LM, Galal TM, Farahat EA, El-Midany MM. The biology of Calotropis procera (Aiton) W.T. Trees. 2015; 29 (2). Trees. 2015;29(2):311-20. doi: 10.1007/ s00468-015-1158-7.

40. Gnanavel V, Palanichamy V. Pharmacognostical studies on leaf and stem of Abrus precatorius. Int J Res Pharm Sci. 2016;7:214-20.

41. Tabasum S, Khare S, Jain K. Macroscopic and microscopic evaluation of Abrus precatorius L. (Gunja), seeds. Int J Pharm Sci Res. 2017;8:2631-5.

42. Ozoemenam Al, Ebenezar OB, Chinyem NB. Comparative anatomy of Abrus adanson species in parts of tropical West Africa. Asian J Plant Sci. 2007;6(5):73240. doi: 10.3923/ajps.2007.732.740. 
43. Zhang Z, Lu L, Liu Y, Qing L. Comparing and authenticating on anatomical aspects of Abrus cantoniensis and Abrus mollis by microscopy. Pharmacogn Res. 2015;7(2):148-55. doi: 10.4103/0974-8490.150526, PMID 25829788.

44. Balázs VL, Filep R, Ambrus T, Kocsis M, Farkas Á, Stranczinger S, et al. Ethnobotanical, historical and histological evaluation of Helleborus L. genetic resources used in veterinary and human ethnomedicine. Genet Resour Crop Evol. 2020;67(3):781-97. doi: 10.1007/s10722-019-00876-5.

45. LiYL, Shang MY, Chen JJ, Cai SQ. Application of microscopy for discrimination of eight Swertia species utilized in the traditional Chinese Medicine "Qingyedan". Microsc Res Tech. 2013;76(3):296-310. doi: 10.1002/jemt.22167,
PMID 23296983.

46. Cortella AR, Pochettino ML. Starch grain analysis as a Microscopic Diagnostic Feature in the Identification of Plant Material. Econ Bot. 1994;48(2):171-81. doi: 10.1007/BF02908212

47. Kumar P, Kumar B, Singh K, Gairola S. Morpho-anatomical standardization of six important RET medicinal plants of Astavarga group from Western Himalaya India. Res Rev Biotech Biosci. 2018;5:1-14.

48. Singh K, Kumar P, Kumar B, Lone JF, Sharma PR, Gairola S. Morpho-anatomical and palynological standardization and DNA bar coding of Fritillaria cirrhosa D. Don (Syn. Fritillaria roylei hook. Plant Arch. 2020;20:1304-13.

\section{GRAPHICAL ABSTRACT}

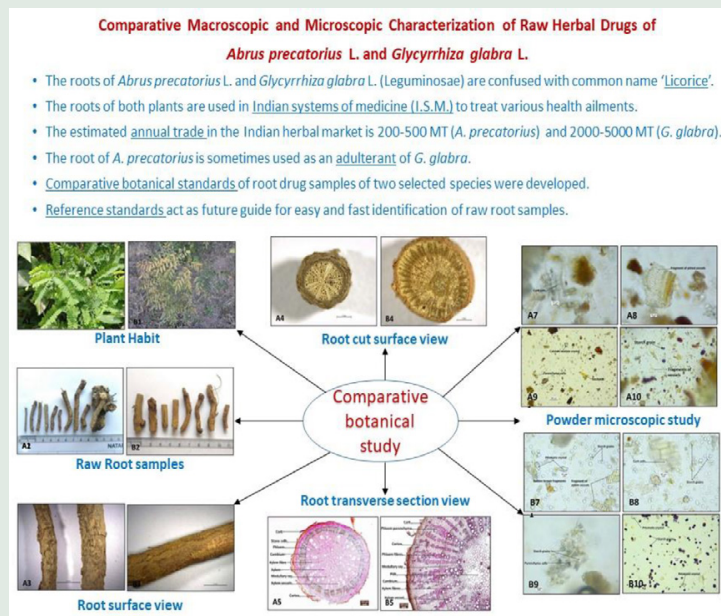

\section{SUMMARY}

The roots of Abrus precatorius L. and Glycyrrhiza glabra L., belonging to family Leguminosae are used in Indian systems of medicine (I.S.M.) to treat various health ailments. The root samples of $G$. glabra are reported with comparatively higher trade value (2000$5000 \mathrm{MT}$ ) as compared to $A$. precatorius (200-500 MT). Raw herbal samples of $A$. precatorius is sometimes used as an adulterant of $G$. glabra due to confusion in common name 'Licorice'. Due to lack of proper reference identification standards, the correct identification of raw root samples of unknown background becomes difficult. Present study involved comparative botanical study of root samples of both species in terms of the macroscopic and microscopic characters. The comparative study revealed significant botanical characters that can potentially distinguish raw root samples of genuine 'Liquorice' ( $G$. glabra) from the adulterant drug (A. precatorius). The macroscopic and microscopic characters identified in this comparative study can be used as reference standard for future identification and for distinction of raw drug samples of these two species traded in herbal market.

\section{ABOUT AUTHORS}

Pankaj Kumar, M.Sc, is presently working as Senior Project Associate at Plant Sciences Division, CSIR-Indian Institute of Integrative Medicine, Canal Road, Jammu, India. His areas of research include botanical standardization of raw herbal drug samples especially from Western Himalayan region.

Javaid Fayaz Lone, M.Sc, is presently working as Project Associate at Plant Sciences Division, CSIR-Indian Institute of Integrative Medicine, Canal Road, Jammu, India. His areas of research include taxonomy and molecular identification of aromatic and medicinal plants from Western Himalaya.

Dr. Sumeet Gairola, Ph.D, is currently working as Senior Scientist at Plant Sciences Division, CSIR-Indian Institute of Integrative Medicine, Canal Road, Jammu, India. His areas of research include the field of taxonomy and ecology of Western Himalayan flora. He has extensively worked on the RET medicinal and aromatic plants of the region, and ethnomedicinal plants used by various indigenous communities of Western Himalaya.

Cite this article: Kumar P, Lone JF, Gairola S. Comparative Macroscopic and Microscopic Characterization of Raw Herbal Drugs of Abrus precatorius L. and Glycyrrhiza glabra L.. Pharmacog Res. 2022;14(1):100-6. 